\title{
Can C-phycocyanin be used as a sperm protector?
}

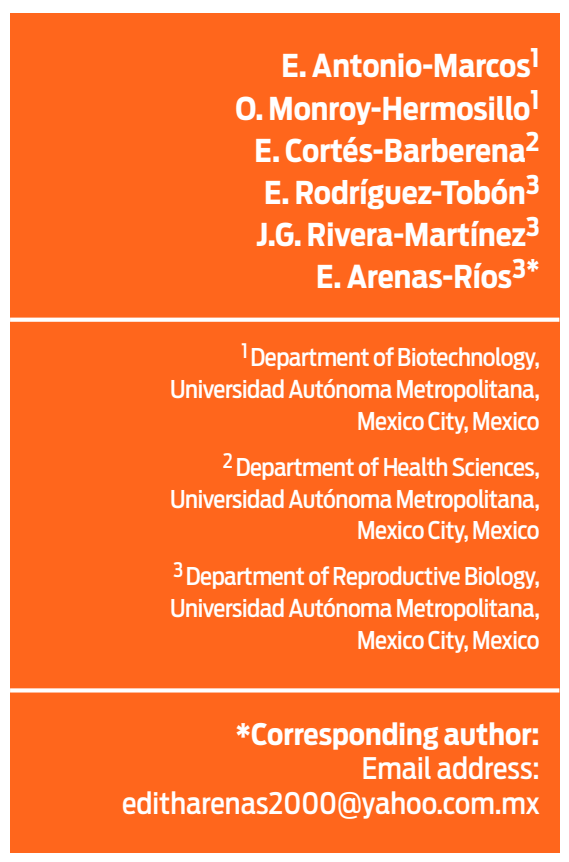

Accepted: $\quad 2018-11-22$

Published: 2019-02-05

Additional information and declarations can be found on page 8

(c) Copyright 2018 E. Antonio-Marcos et al.

open access $\boldsymbol{\gamma}$

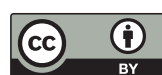

Distributed under Creative Commons CC-BY 4.0

\begin{abstract}
C-phycocyanin (C-PC) is a biocompound extracted from Arthrospira maxima. It is a chromophore-protein complex, with antioxidant properties. Its ability to prevent oxidative stress allows for diverse medical applications. This study evaluates the use of C-PC as a protein supplement and an antioxidant for in-vitro sperm preservation in a short-term extender. Viability, progressive motility, DNA damage and percentage of reactive oxygen species where assessed in Swine (Sus scrofa domesticus) sperm stored for up to 72 hours at $4{ }^{\circ} \mathrm{C}$. Treatments with C-PC had the following concentrations: 0, 34.5, 69, 138 and $207 \mu \mathrm{g} \mathrm{mL}{ }^{-1}$. Progressive motility and percentage of sperm with undamaged DNA were unchanged (20\%) after storage for 48 hours using the 138 ug $\mathrm{mL}-1$ C-PC concentration.
\end{abstract}

Keywords: C-phycocyanin, sperm refrigeration, DNA damage, progressive motility, extender

\section{Cite this as:}

Antonio Marcos EG, Monroy Hermosillo O, Cortés Barberena E, Rodríguez Tobón E, Rivera Martínez JG, Arenas Ríos E. Can C-phycocyanin be used as a sperm protector? Veterinaria México OA. 2018;5(4). doi: 10.22201/fmvz.24486760e.2018.4.642 


\section{Introduction}

C-Phycocyanin (C-PC) is a constituent biopigment of Arthrospira maxima, a cyanobacteria native to the alkaline habitat of the Texcoco Lake in Central Mexico. It can be overproduced when these bacteria are grown under high urea and salt concentrations (yields of $220 \mathrm{mg} \mathrm{C-PC} \mathrm{g}{ }^{-1}$ biomass). ${ }^{1}$ C-PC has a protein and a non-protein component (containing three chromophores), which can be very reactive to other proteins. The protein element of C-PC has two $\alpha$ and a $\beta$ subunits. When added as a protein supplement in an extender for semen preservation, it can react with membrane proteins of cells. The protein and the non-protein (phycocyanobilin) elements of the compound are coupled through cystein and thioether linkages. ${ }^{2}$ The non-protein component is able to capture and prevent the formation of reactive nitrogen and oxygen species (RNS \& ROS) through the scavenging of hydroxyl and $(\bullet \mathrm{OH})$ alkoxyl $(\mathrm{RO} \bullet)$ radicals, hydrogen peroxide $\left(\mathrm{H}_{2} \mathrm{O}_{2}\right)$ and nitric oxide $(\mathrm{NO} \bullet)^{2}$ It can thus delay, reduce or avert essential molecule impairment, ${ }^{3}$ caused by the unbalance of ROS production and an alteration in the antioxidant defense system. ${ }^{4,5}$ Oxidative stress (OS) is related to the ageing process of cells. ${ }^{2,6}$ OS can also lead to a loss of cell membrane integrity due to increased permeability, enzyme inactivation, DNA damage and cell apoptosis. ${ }^{7,8}$ For sperm in particular, these alterations are related to male infertility. ${ }^{9}, 10$ Notably, during mammal sperm capacitation, which is an oxidative process, a limited amount of ROS production is needed. 11,12

Pig sperm is considered a model system to study oxidative stress due to an abundant presence of unsaturated fatty acids in the plasmatic membrane that can render it highly vulnerable. ${ }^{13,14}$ Even if boar semen can be cryopreserved, ${ }^{13}$ the best results for transient storage are attained at $15-17^{\circ} \mathrm{C} .15,16$ It seems that when boar sperm is stored at $16^{\circ} \mathrm{C}$ it has a lower susceptibility to DNA damage, as alterations in chromatin packaging occur at lower temperatures $\left(5{ }^{\circ} \mathrm{C}\right) .{ }^{17}$ However, storing sperm at $15-17{ }^{\circ} \mathrm{C}$ could be difficult under field conditions, since regular available refrigerators keep a fairly constant $4{ }^{\circ} \mathrm{C}$ temperature.

Sperm storage is essential for reproductive biotechnologies such as artificial insemination. Extenders used for semen processing need to protect sperm, inhibit bacterial growth, provide an energy source, and ensure proper $\mathrm{pH}$ and osmotic pressure. A wide range of commercial extenders have been developed for optimal preservation of boar semen at 15 a $17^{\circ} \mathrm{C}$. These extenders are intended for short ( 3 to 4 days), medium ( 5 to 6 days), long ( 7 to 8 days), or extra-long term (more than 8 days) storage. However, information regarding extender effects on fertility of refrigerated boar sperm is scarce. ${ }^{15}$

Kortowo-3 is a short-term extender which has been used for boar semen storage at $5{ }^{\circ} \mathrm{C} .{ }^{18}$ When protein is added to the extender, spermatic parameters are enhanced. ${ }^{17}$ Egg yolk is frequently used as a source of protein for ram and boar semen extenders. ${ }^{19,20}$ Furthermore, both egg yolk and milk are commonly used as membrane cryoprotectors in refrigerated media for long-term semen preservation. These components can be used either alone or in combination with other proteins. ${ }^{19}$

The aim of this study was to evaluate the effect of adding the C-PC compound to the Kortowo-3 extender on refrigerated $\left(4^{\circ} \mathrm{C}\right)$ boar semen parameters. 


\section{Material and methods}

\section{Chemicals}

Used chemicals were of the highest available purity. Salts were purchased from Sigma-Aldrich, Meyer and JT Baker; Eosin was acquired from Merck; and nigrosine, acridine orange, gentamicin sulfate and 2', 7'-dichloridefluoresceine diacetate from Sigma-Aldrich.

Duragen solution (Magapor-Spain), an extender typically used for extra longterm storage, was used for semen transport.

\section{C-PC source}

C-PC was obtained from the A. maxima LJGR1 strain from the collection of the Ecology and Taxonomy of Continental Algae Laboratory at the Universidad Nacional Autónoma de México (UNAM). Bacteria were grown under stress conditions to incite overproduction of C-PC, which was subsequently extracted by sonication at $45^{\circ} \mathrm{C}$, purified (0.7) and freeze-dried until used. ${ }^{1}$

\section{Boar sperm}

Five one-year old boars (Pietrain) were used for the study. Fourteen semen samples were collected, filtered, diluted in Duragen solution, and transported at $17{ }^{\circ} \mathrm{C}$ (protected from light), to the laboratory. Inclusion parameters for ejaculates were set at more than 90\% viability, $70 \%$ progressive motility, less than 10\% abnormalities and over 25 million sperm cells $\mathrm{mL}^{-1} .21,22$ Twelve samples attained adequate quality to be included in the experiments.

To assess sperm motility, $5 \mu \mathrm{L}$ of the sample (around 200 cells) were observed under a bright field microscope at 40X to identify: progressive motility, non-progressive motility and immobile cells.

To calculate spermatozoa concentration an improved Neubauer hemocytometer was used. ${ }^{22}$

Viability and sperm abnormalities were examined using an eosine-nigrosine stain. A slide was prepared by mixing $5 \mu \mathrm{L}$ of the semen sample with $5 \mu \mathrm{L}$ of a $10 \%$ eosine-nigrosine solution on a slide, left to dry for 30 seconds and observed using a bright field microscope. Identification of unstained live cells and of purple-stained dead cells was done with at 40X magnification. Percentage of cells presenting morphological abnormalities or exhibiting excess residual cytoplasm was determined with a $100 \mathrm{X}$ objective. ${ }^{22}$

\section{Sperm storage with C-PC}

Semen samples were centrifuged upon arrival to the laboratory at $600 \mathrm{~g}$ for 10 minutes (in a Zeigen $\mathrm{CH} 90-1 \mathrm{~A}$ centrifuge) to remove the Duragen solution. Sediment was then diluted to a $30 \times 10^{6}$ spermatozoa $\mathrm{mL}^{-1}$ cell count, using the Kortowo-3 extender (fructose $69.3 \mathrm{mM}$, sodium citrate $64.6 \mathrm{mM}, \mathrm{Na}_{2}$-EDTA $8 \mathrm{mM}$, potassium acetate $14.2 \mathrm{mM}$ and gentamicine $0.25 \mathrm{~g} \mathrm{~L}^{-1}$ at $\mathrm{pH}$ 6.8)..$^{18}$ Diluted samples were divided, and five different C-PC doses were added to the solution $(0,34.5,69,138$ and $207 \mu M)$. Samples were left for 2 hours at room temperature and subsequently refrigerated at $4{ }^{\circ} \mathrm{C}$ for 24,48 and 72 hours. At each time point, semen samples were assessed for sperm motility, viability, DNA damage and ROS production. 


\section{Assessment of DNA damage}

Flow cytometry assessment of DNA damage was performed with a $488 \mathrm{~nm}$ argon blue laser with acridine orange to show fluorescence (FACScan, Becton-Dickinson). A green color emision $(530 \mathrm{~nm}$ ) revealed undamaged double strand DNA, whereas a red/orange emission $(620 \mathrm{~nm})$ indicated damage on a single DNA strand. ${ }^{23-25}$

\section{Quantification of reactive oxygen species (ROS)}

Intracellular ROS production $\left(\mathrm{H}_{2} \mathrm{O}_{2}, \mathrm{HO} \bullet\right.$ and $\left.\mathrm{ONOO} \bullet\right)$ in sperm was quantified by flow cytometry (480 nm/520 nm; FACScan, Becton-Dickinson, San Jose, CA, USA), using 2',7' dichlorofluoreseine diacetate (DCFH-DA), a cell-permeable probe that is highly sensitive to cellular oxidation and fluoresces when oxidized. Results are expressed as mean fluorescence intensity (MFI) of live cells exhibiting a fluorescent response. ${ }^{26}$ The Flowing software was used to analyze data, which were normalized and expressed as fluorescence index $(\mathrm{Fl})=$ (mean fluorescence intensity * \% input events).

\section{Statistical analysis}

Mean differences were assessed by ANOVA (SPSS 15 software), followed by the Duncan multiple comparisons test. Statistical differences were established at $\mathrm{P}<0.05$. Data are presented as means $\pm \mathrm{SEM}$.

\section{Results and discussion}

Sperm viability decreases after being stored for 24 hours, falling from $90 \%$ to close to $10 \%$ by 72 hours. Sperm viability at $72 \mathrm{~h}$ was higher with the $138 \mu \mathrm{g} \mathrm{mL}-1$ C-PC dose $(16 \pm 6 \%)$. Considering that at least a $20 \%$ viability is required for sperm use in assisted reproduction techniques boar refrigerated sperm would not be fit for use after $72 \mathrm{~h}$ of storage, even with addition of C-PC (Figure 1).

Progressive motility (PMot), which is affected by intracellular ROS production, was close to $90 \%$ in viable sperm before storage (Figure 2), whereas DNA damage was present in near $40 \%$ of all spermatozoa, independently of storage time (Figure 3). Therefore, the proportion of motile sperm that also has undamaged DNA is over $40 \%$ before storage and decreases thereafter with increasing storage time (Figure 4). It seems likely that the protein element of C-PC as sole added protein source to the extender is insufficient for protecting the sperm cell membrane. Conversely, the antioxidant element of C-PC seems to have had a positive effect on controlling intracellular ROS production, as seen by the mean fluorescence intensity (MIF) of viable cells (Figure 5).

Sperm storage at temperatures lower than $5^{\circ} \mathrm{C}$ can induce cold stress on boar spermatozoa, ${ }^{16}$ which can then cause irreversible permeability of cells through loss of integrity of the plasmatic membrane. This may lead to a distorted cell performance and eventually to cell death. Proteins that are diluted in processing media have been able to protect spermatozoa from cold stress and plasmatic membrane destabilization, ${ }^{18}$ and are thus added to extenders used for handling semen. 17,19,20

The Kortowo-3 extender has been used for refrigerated semen studies ${ }^{17,18}$ with reported sperm progressive motility percentages similar to the ones obtained 


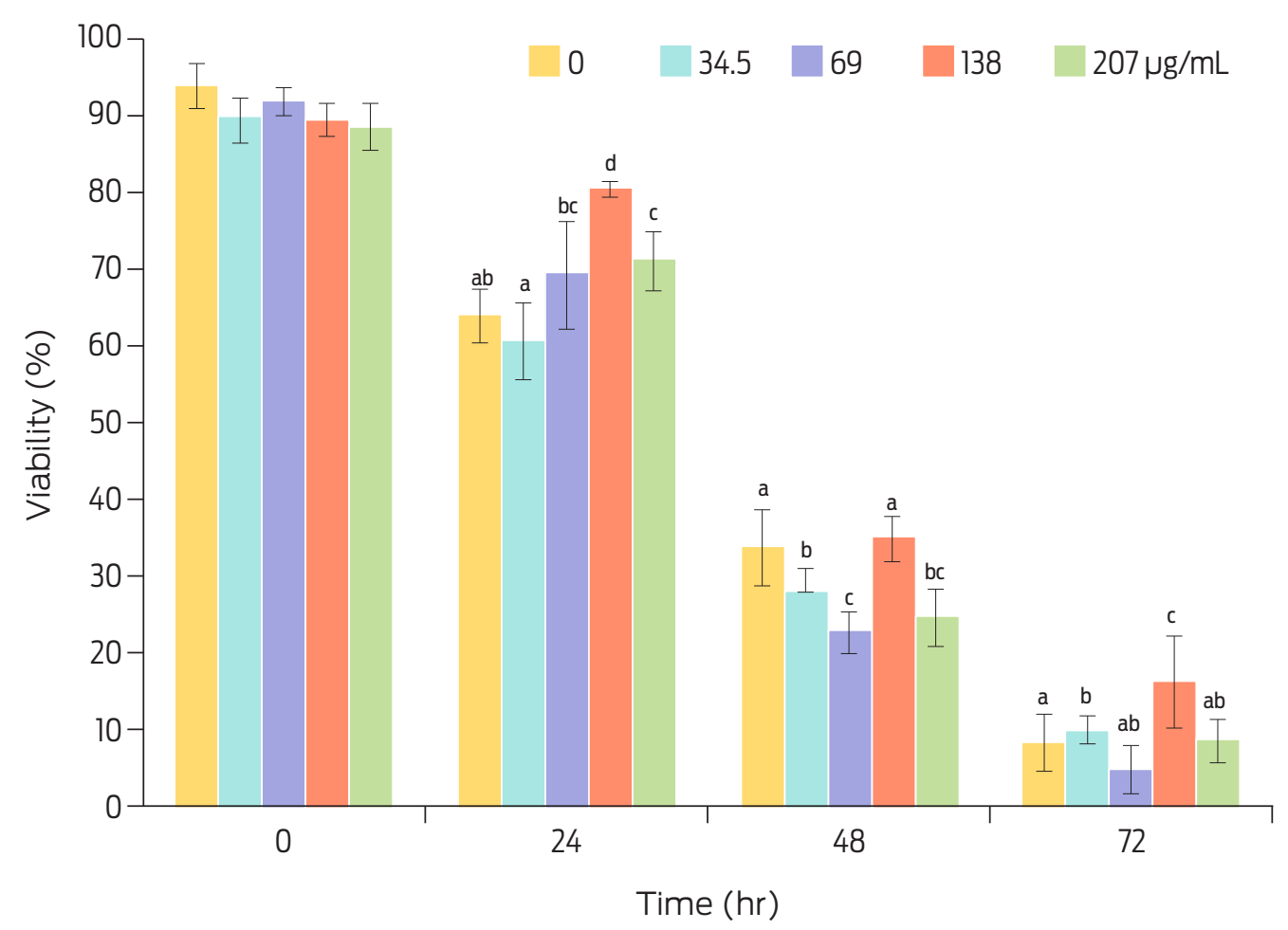

Figure 1. Effect of C-PC dose and storage time (at $4{ }^{\circ} \mathrm{C}$ ), on sperm viability. Values are expressed as means $\pm \mathrm{SEM}$. Different superscripts indicate statistical difference as analyzed by ANOVA and the Duncan multiple comparisons test $(P \leq 0.05)$.

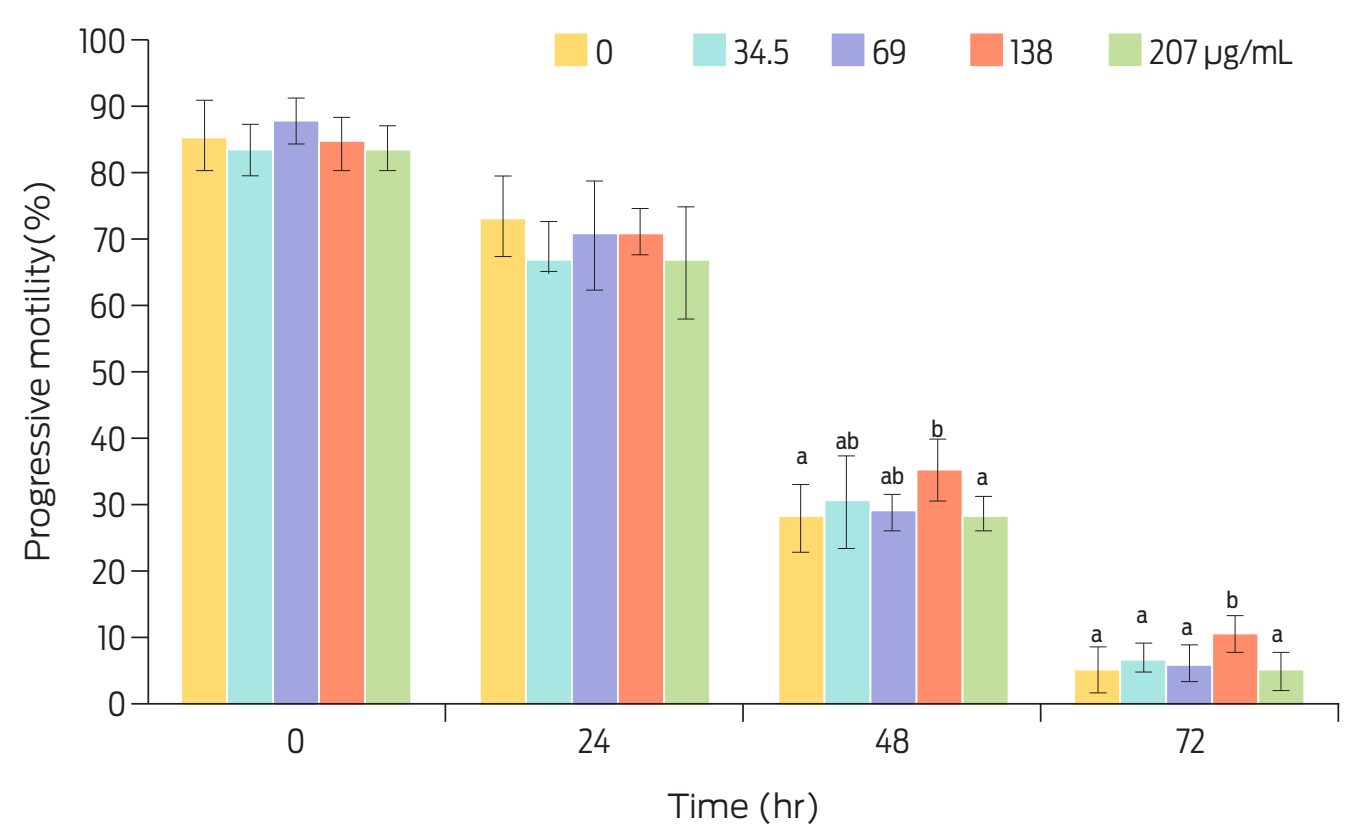

Figure 2. Effect of C-PC dose and storage time (at $4{ }^{\circ} \mathrm{C}$ ) on progressive motility of sperm. Values are expressed as means \pm SEM. Different superscripts indicate statistical difference as analyzed by ANOVA and the Duncan multiple comparisons test $(\mathrm{P} \leq 0.05)$. 


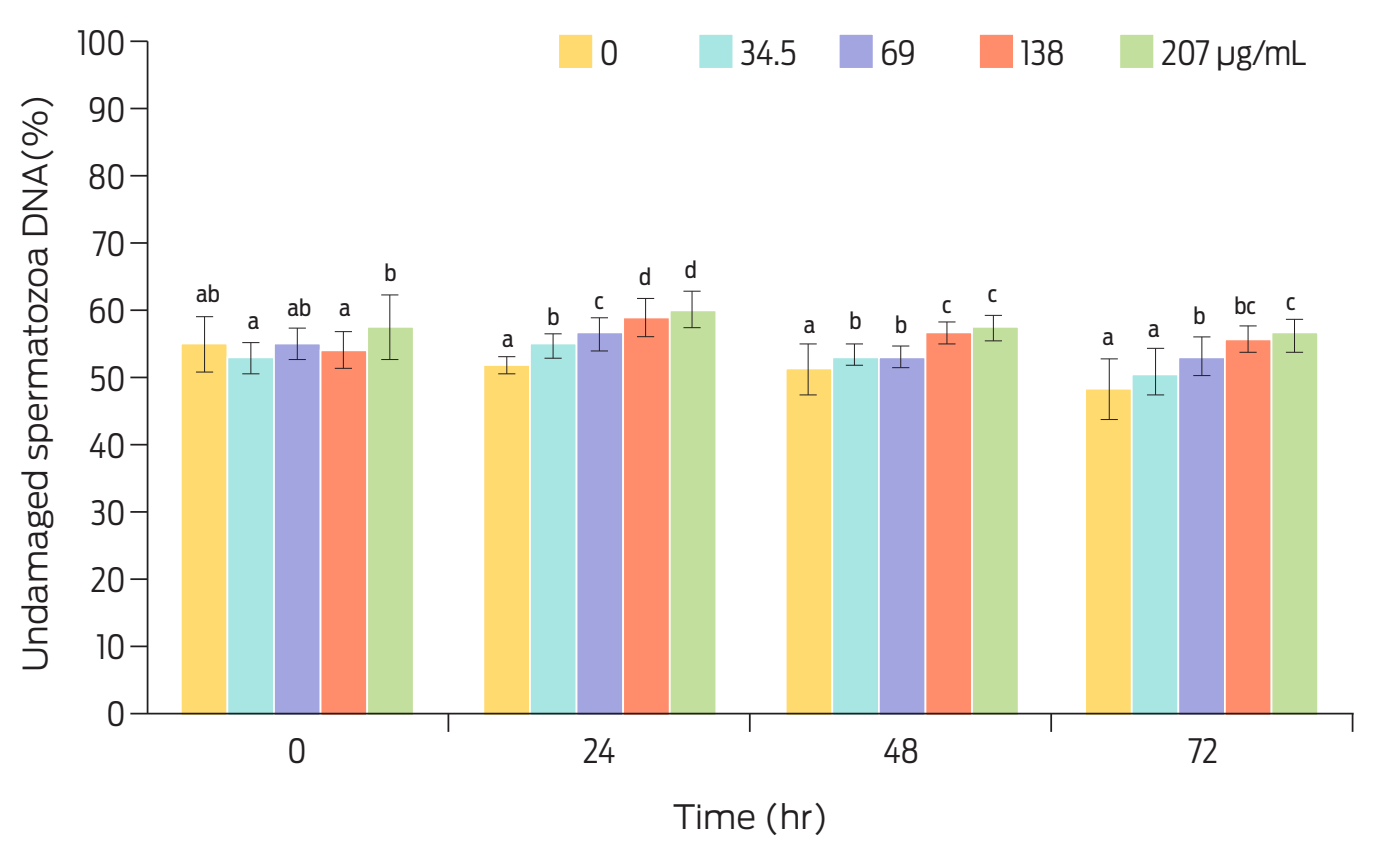

Figure 3. Effect of C-PC dose and storage time (at $4{ }^{\circ} \mathrm{C}$ ), on sperm DNA damage. Values are expressed as means \pm SEM. Different superscripts indicate statistical difference as analyzed by ANOVA and the Duncan multiple comparisons test $(P \leq 0.05)$.

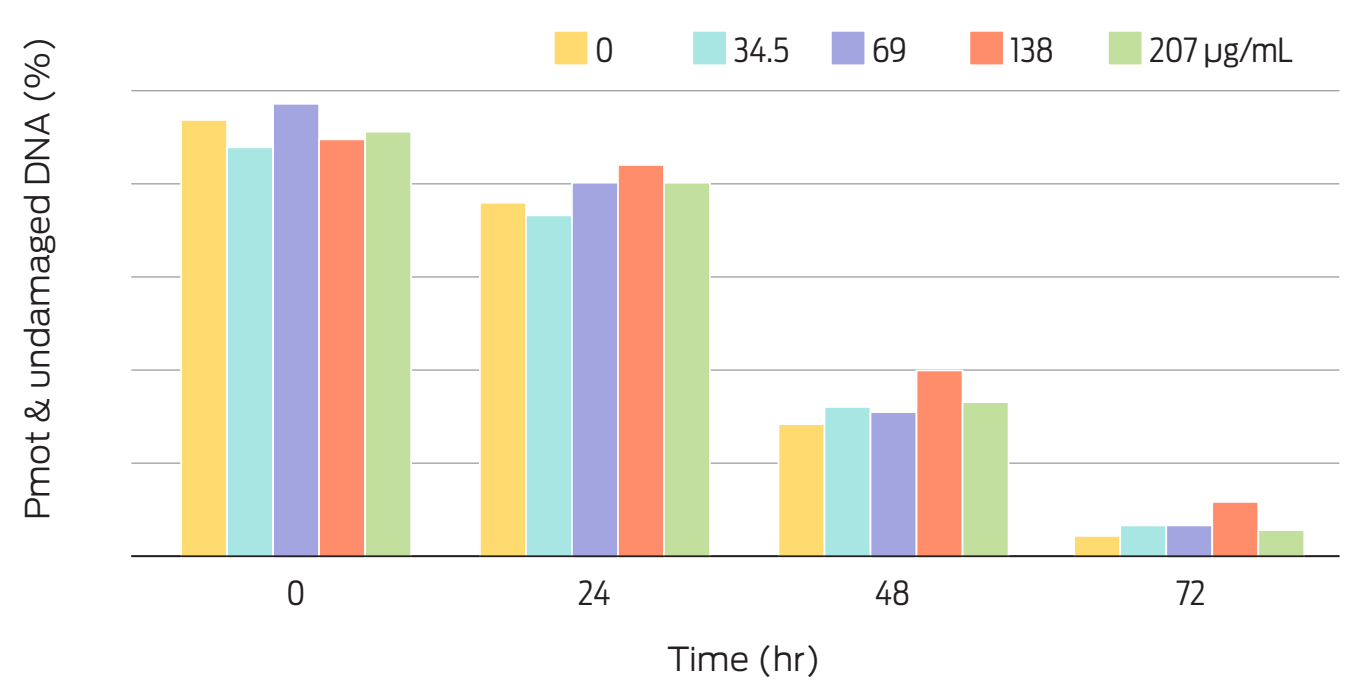

Figure 4. Percentage of PMot sperm with undamaged DNA. Treatments include different C-PC doses and storage times (at $4{ }^{\circ} \mathrm{C}$ ). . PMot=Progressive motility. 


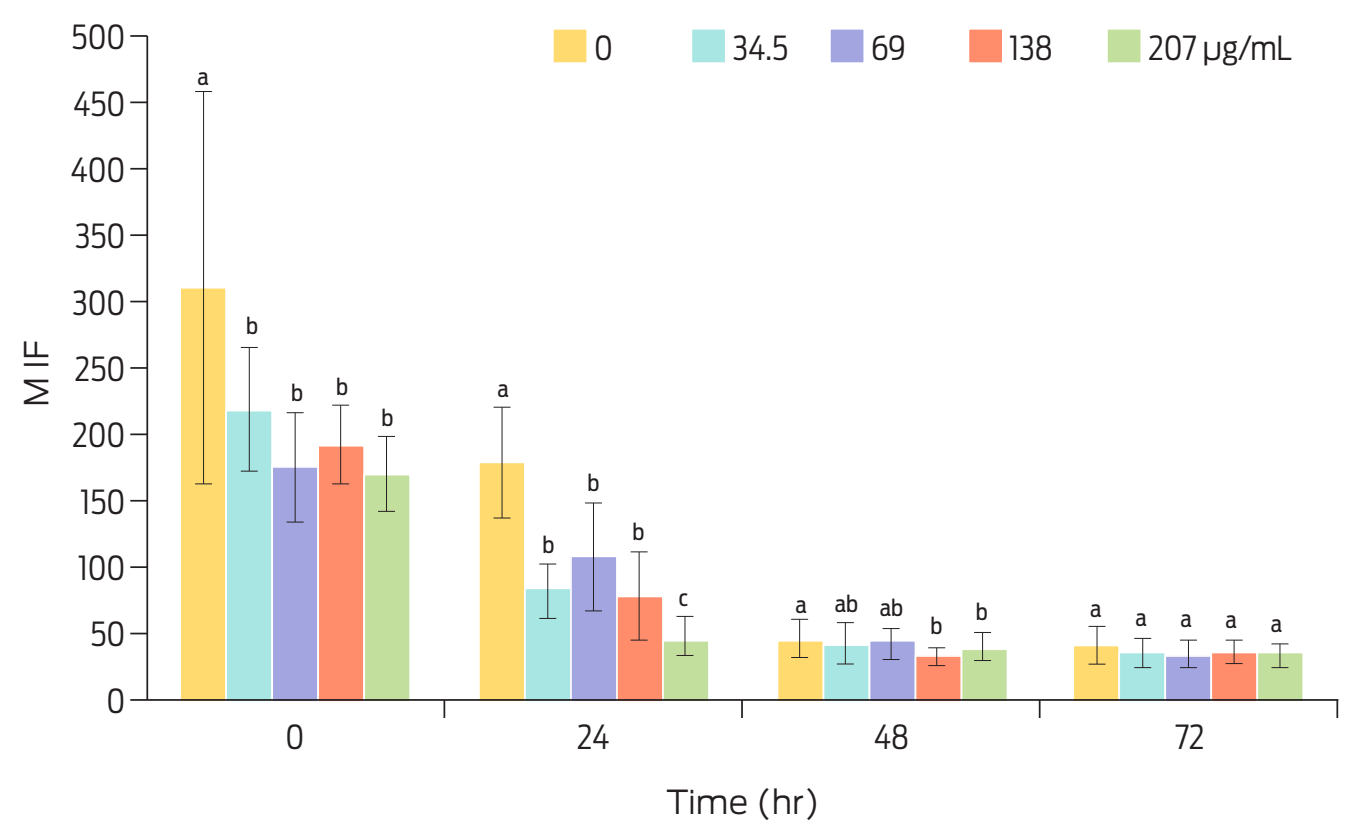

Figure 5. Effect of C-PC dose and storage time (at $4^{\circ} \mathrm{C}$ ), on intracellular ROS production, as seen by percentage of mean fluorescence intensity (MFI) of viable cells. Values are expressed as means \pm SEM. Different superscripts indicate statistical difference as analyzed by ANOVA and the Duncan multiple comparisons test $(P \leq 0.05)$.

in this work. However, if the extender is supplemented with chicken lipoprotein and ostrich egg yolk, PMot is higher (70\%) at 48 hours, than that of semen with an extender that is devoid of added proteins. ${ }^{17}$ Our results show a 35\% of PMot with $138 \mu \mathrm{g}$ of added C-PC mL $\mathrm{mL}^{-1}$ at 48 hours, and a $28 \%$ PMot when no C-PC was added to the extender (Figure 2). Therefore, the C-PC apoprotein does not seem to work as well as other proteins (egg yolk or lipoproteins) to increase this spermatic parameter. Boar DNA has a higher resistance to the freezing-thawing process than other mammalian spermatozoa. This resistance seems to be related to the amount of cysteine residues in protamine 1 which forms disulphide bonds that stabilize chromatin. Nonetheless cysteine residues have also been negatively related to sperm susceptibility to oxidative stress. In fact, bioactive antioxidant compounds of mate tea (such as flavonoids) can protect boar sperm DNA. ${ }^{27}$ These seemingly contradictory data can help explain why percentage of sperm cells without DNA damage appears to increase with some of the added C-PC doses, as well as over time (Figure 3). Extender should protect sperm without interfering with fertility or prolificacy rates. ${ }^{15}$ Progressive motility on sperm with undamaged DNA after 48 hours of storage was still close to 20\% (Figure 4).

\section{Conclusion}

The protein element of C-PC does not have a positive effect on sperm viability when added to the Kortowo-3 short-term extender. However, the antioxidant portion of the C-PC compound appears to decrease ROS production in cells, and could be therefore used as antioxidant in short and long-term storage extenders. 


\section{Funding}

This article was possible thanks to the funding assigned by Conacyt and UAM to the working group of Dr. Oscar Monroy-Hermosillo and Dr. Edith Arenas-Ríos.

\section{Acknowledgements}

This study was supported by CONACYT, grant No. 211653 .

\section{Conflicts of interest}

There are no conflicts of interests for the publication of this article.

\section{Author contributions}

AME and ARE (Experimental design and data analyzes),

RTE (Experimental work and data analyzes),

$\mathrm{MHO}$ (data analyzes),

COB (Flow cytometry analyses)

RMJ (Laboratory work assistant).

\section{References}

1. Antonio-Marcos E, Hernández-Vázquez L, Olguín EJ, Monroy O, Navarro-Ocaña A. C-phycocyanin from Arthrospira maxima LJGR1: production, extraction and protection. J Adv Biotechnol. 2016;5(2):659-66.

2. Fernández-Rojas B, Hernández-Juárez J, Pedraza-Chaverri J. Nutraceutical properties of phycocyanin. J Funct Foods. 2014;2:375-92.

3. Niki E. Assessment of antioxidant capacity in vitro and in vivo. Free Radic Biol Med. 2010;49:503-15.

4. Aitken RJ, Lambourne S, Gibb Z. The John Hughes memorial lecture: aspects of sperm physiology-oxidative stress and the functionality of stallion spermatozoa. J Equine Vet Sci. 2014;34:17-27.

5. Mata-Campuzano M, Álvarez-Rodríguez M, Tamayo-Canul J, López-Urueña E, Álvarez M. Refrigeration storage of ram sperm in presence of Trolox and GSH antioxidants: effect of temperature, extender and storage time. Anim Reprod Sci. 2014;151:137-47.

6. Li Y-J, Han Z, Ge L, Zhou C-J, Liang C-G. C-phycocyanin protects against low fertility by inhibiting reactive oxygen species in aging mice. Oncotarget. 2016;7(14):17393-409.

7. Walczak-Jedrzejowska R, Wolski JK, Slowikowska-Hilczer J. The role of oxidative stress and antioxidants in male fertility. Cent European J Urol. 2012;60-7.

8. Amini MR, Kohram H, Shahaneh AZ, Zhandi M, Sharideh H, Nabi MM. The effects of different levels of vitamin $\mathrm{E}$ and vitamin $\mathrm{C}$ in modified Beltsville extender on rooster post-thawed sperm quality. Call Tissue Bank. 2015;16:587-92.

9. Agarwal A, Roychoudhury S, Bjugstad KB, Cho C-L. Oxidation-reduction potential of semen: what is its role in the treatment of male infertility? Ther Adv Urol. 2016;8(5):302-18.

10. Nekoonam S, Nashtaei MS, Naji M, Zangi BM, Amidi F. Effect of Trolox on sperm quality in normozospermia and ologozospermia during cryopreservation. Cryobiology. 2016;72:106-11. 
11. Aitken RJ, Smith TB, Jobling MS, Baker MA, De luliis GN. Oxidative stress and male reproductive health. Asian J Androl. 2014;16:31-8.

12. O'Flaherty C. Redox regulation of mammalian sperm capacitation. Asian J Androl. 2015;17:583-90.

13. Jin Hwang Y, Young Kim D. Effects of ginsenoside-Rg1 on post-thawed miniature pig sperm motility, mitochondria activity, and membrane integrity. J Emb Trans. 2013;28(1):63-71.

14. Gadea J. Semen extenders used in the artificial insemination of swine. SJAR. 2003;1(2):17-27.

15. Pinart E, Yeste M, Prieto-Martínez N, Reixach J, Bonet S. Sperm quality and fertility of boar seminal doses after 2 days of storage: Does the type of extender really matter? Theriogenology. 2015;83:1428-37.

16. Teixeira SMP, Chaveiro A, Moreira da Silva F. The effects of three extenders on refrigerated boar semen. S Afr J Anim Sci. 2015;45(1):82-8.

17. Fraser $L$, Strzeżek J. The use of comet assay to assess DNA integrity of boar spermatozoa following liquid preservation at $5{ }^{\circ} \mathrm{C}$ and $16{ }^{\circ} \mathrm{C}$. Folia Histochem Cytobiol. 2004;42(1):49-55.

18. Dziekonska, A. \& Strzeżek, J. Boar variability affects sperm metabolism activity in liquid stored semen at $5{ }^{\circ} \mathrm{C}$. Pol J Vet Sci. 2011;14(1):21-7.

19. Del Valle I, Gómez-Durán A, Holt WV, Muiño-Blanco T, Cebrián-Pérez JA. Soy lecithin interferes with mitochondrial fuction in frozen-thawed ram spermatozoa. J Androl. 2012;33:717-25.

20. Malo C, Gil L, Cano R, Martínez F, Galé I. Antioxidant effect of rosemary (Rosmarinus officinalis) on boar epididymal spermatozoa during cryopreservation. Theriogenology. $2011 ; 75: 1735-41$.

21. Verstegen J, Iguer-Ouada M, Onclin K. Computer assisted semen analyzers in andrology research and veterinary practice. Theriogenology. 2001;57:149-79.

22. WHO (World Health Organization). WHO Laboratory manual for the examination and processing of human semen, 5th ed. Charter 2, 2010. p. 7-114.

23. Evenson D, Jost L. Sperm chromatin structure assay is useful for fertility assessment. Methods Cell Sci. 2000;22:169-89.

24. Gadella BM, Harrison RA. Capacitation induces cyclic adenosine 3', 5'-monophosphate-dependent, but apoptosis-unrelated, exposure of aminophospholipids at the apical head plasma membrane of boar sperm cells. Biol Reprod. 2002;67:340-50.

25. Arenas-Ríos E, Rosado-García A, Cortés-Barberena E, Königsberg M, Arteaga-Silva $M$, Rodríguez-Tobón $A$, et al. Reactive oxygen species production and antioxidant enzyme activity during epididymal sperm maturation in Corynorhinus mexicanus bats. Reprod Biol. 2016;16:78-86.

26. Mayorga-Torres BJM, Camargo M, Cadavid AP, du Plessis SS, Cardona Maya WD. Are oxidative stress markers associated with unexplained male infertility? Andrologia. 2016;1-7.

27. Luño V, Gil L, Olaciregui M, Jerez RA, de Blas I, Hozbor F. Antioxidant effect of lemon balm (Melissa officinalis) and mate tea (Ilex paraguensys) on quality, lipid peroxidation and DNA oxidation of cryopreserved boar epididymal spermatozoa. Andrologia. 2015;47:1004-11. 